\title{
DETERMINAN PERILAKU WANITA MELAKUKAN DETEKSI DINI KANKER SERVIKS DI KABUPATEN LAMPUNG SELATAN
}

\author{
Siti Mariam ${ }^{1}$, Atikah Adyas ${ }^{2}$, William Arisandi ${ }^{3}$
}

\author{
${ }^{1}$ Mahasiswa Prodi Magister Kesehatan Masyarakat Universitas Mitra Indonesia \\ Email: sitimariam651@gmail.com \\ ${ }^{2}$ Dosen Prodi Magister Kesehatan Masyarakat Universitas Mitra Indonesia \\ Email: adyas_atikah@yahoo.com \\ ${ }^{3}$ Dosen Prodi Magister Kesehatan Masyarakat Universitas Mitra Indonesia \\ Email: william@gmail.com
}

\section{ABSTRACT : DETERMINANTS OF WOMEN BEHAVIOR IN THE EARLY DETECTION OF CANCER SERVICES IN LAMPUNG SELATAN DISTRICT}

Introduction : Cervical cancer is the most common cancer in women with an estimated 530,000 new case. The problem facing cervical cancer prevention is the low coverage of early cervical cancer detection rates. In South Lampung in 2018 the number of women of childbearing age of 30-50 years who had undergone IVA examination was 44,913 people (30.5\%) with positive results of 624 cases $(1.39 \%)$.

Objective: To determine the relationship of supporting factors with the behavior of women in early detection of cervical cancer.

Method: This type of research is quantitative. Analytical research design with cross-sectional approach. The population is all WUS in South Lampung Regency as many as 148,499 people with a sample of 170 respondents. Data analysis used univariate analysis with percentages, bivariate analysis with Chi Square and multivariate analysis with multiple logistic regression predictive models.

Result : The results showed that there was a relationship between the supporting factors namely knowledge $(p=0.016)$, attitude $(p=0.014)$ and education $(p=0.015)$ with the behavior of women doing early detection of cervical cancer. There is a relationship between the reinforcing factors of husband / family support $(p=0.001)$, the role of health workers $(p=0.001)$ and friend support (0.003) with the behavior of women doing early detection of cervical cancer. There is a relationship between enabling factors for access to information $(p=0.001)$, access to health services $(p=0,000)$ and affordability $(p=0.036)$ and the behavior of women in early detection of cervical cancer. The most dominant variable related to the behavior of women doing early detection of cervical cancer is the variable access to health services with an $O R$ value of 15.46 .

Conclusion : For this reason, it is hoped that the Puskesmas in South Lampung will continue to mobile to the villages to get closer to the target access to health services with the availability of available resources even though BPJS cannot cover the cost of IVA examinations anymore. Continue to increase promotion efforts through Information and Education Communication (IEC) on early detection of cervical cancer by the IVA method. .

Keywords : Determinant, Behavior, Early Detection of Cervical Cancer, Age Women Lush (WUS)

Siti Mariam ${ }^{1}$, Atikah Adyas ${ }^{2}$, William Arisandi ${ }^{3}$

${ }^{1}$ Mahasiswa Prodi Magister Kesehatan Masyarakat UMI. Email: sitimariam651@gmail.com

${ }^{2}$ Dosen Prodi Magister Kesehatan Masyarakat UMI. Email: adyas_atikah@yahoo.com

${ }^{3}$ Dosen Prodi Magister Kesehatan Masyarakat UMI. Email: william@gmail.com 


\section{INTISARI : DETERMINAN PERILAKU WANITA MELAKUKAN DETEKSI DINI KANKER SERVIKS DI KABUPATEN LAMPUNG SELATAN}

Latar Belakang : Kanker serviks merupakan kanker paling sering keempat pada wanita dengan perkiraan 530.000 kasus baru, masalah yang menghadang dalam penanggulangan kanker serviks tersebut adalah masih rendahnya angka cakupan deteksi dini kanker serviks. Di Lampung Selatan pada tahun 2018 jumlah wanita usia subur 30-50 tahun yang telah dilakukan pemeriksaan IVA sebanyak 44.913 orang $(30,5 \%)$ dengan hasil positif sebanyak 624 kasus $(1,39 \%)$.

Tujuan: Diketahui Hubungan factor pendukung dengan perilaku wanita melakukan deteksi dini kanker serviks.

Metode Penelitian : Jenis penelitian adalah kuantitatif. Desain penelitian analitik dengan pendekatan crosssectional. Populasi adalah semua WUS yang berada di Kabupaten Lampung Selatan sebanyak 148.499 orang dengan jumlah sampel 170 responden. Analisis data menggunakan analisis univariat dengan persentase, analisis bivariat dengan Chi Square dan analisis multivariat dengan regresi logistic berganda model prediktif.

Hasil : Hasil penelitian menunjukkan bahwa ada hubungan faktor pendukung yaitu pengetahuan $(p=0,016)$, sikap $(p=0,014)$ dan pendidikan $(p=0,015)$ dengan perilaku wanita melakukan deteksi dini kanker serviks. Ada hubungan faktor penguat dukungan suami/keluarga $(p=0,001)$, peran petugas kesehatan $(p=0,001)$ dan dukungan teman $(0,003)$ dengan perilaku wanita melakukan deteksi dini kanker serviks. Ada hubungan faktor pemungkin akses informasi $(p=0,001)$, akses menuju ke pelayanan kesehatan $(p=0,000)$ dan keterjangkauan biaya $(p=0,036)$ dengan perilaku wanita melakukan deteksi dini kanker serviks. Variabel yang paling dominan berhubungan dengan perilaku wanita melakukan deteksi dini kanker serviks adalah variabel akses ke pelayanan kesehatan dengan nilai OR sebesar 15,46.

Kesimpulan : Diharapkan Puskesmas di Lampung Selatan tetap melakukan mobile ke desa untuk mendekatkan akses sasaran ke pelayanan kesehatan dengan ketersediaan sumber daya yang ada meskipun BPJS tidak dapat mengcover biaya pemeriksaan IVA lagi. Terus meningkatkan upaya promosi melalui Komunikasi Informasi dan Edukasi (KIE) tentang deteksi dini kanker serviks dengan metode IVA.

Kata Kunci : Determinan, Perilaku, Deteksi Dini kanker Serviks, Wanita Usia Subur (WUS)

\section{PENDAHULUAN}

Kanker serviks merupakan kanker paling sering keempat pada wanita dengan perkiraan 530.000 kasus baru, yang mewakili 7,9\% dari semua kanker wanita. Pada tahun 2015 sekitar 90\% kematian atau sebanyak 270.000 akibat kanker serviks terjadi di negara berpenghasilan rendah dan menengah(World Health Organization,
2017). Perkiraan American Cancer Society untuk kanker serviks di Amerika Serikat untuk tahun 2018 adalah sekitar 13.240 kasus baru kanker serviks invasif. Sekitar 4.170 wanita akan meninggal akibat kanker serviks (American Cancer Society, Januari 2018). Di Hongkong, kanker serviks adalah kanker ketujuh yang paling umum di antara wanita dengan

Siti Mariam ${ }^{1}$, Atikah Adyas², William Arisandi ${ }^{3}$

${ }^{1}$ Mahasiswa Prodi Magister Kesehatan Masyarakat UMI. Email: sitimariam651@gmail.com

${ }^{2}$ Dosen Prodi Magister Kesehatan Masyarakat UMI. Email: adyas_atikah@yahoo.com

${ }^{3}$ Dosen Prodi Magister Kesehatan Masyarakat UMI. Email: william@gmail.com 
500 kasus baru di tahun 2015, menyumbang $3,3 \%$ dari semua kasus kanker baru pada wanita (Soerjomataram, 2017). Berdasarkan data Riset Kesehatan Dasar (Riskesdas) tahun 2018, prevalensi tumor/kanker di Indonesia adalah 1,4 per 1000 penduduk atau sebesar 447.097 orang. Prevalensi kanker tertinggi terdapat di DI Yogyakarta 4,9 per 1000 penduduk, diikuti Sumatera Barat 2,6 per 1000 penduduk, Gorontalo 2,4 per 1000 penduduk, DKI Jakarta 2,2 per 1000 penduduk dan Bali 1,9 per 1000 penduduk. Sedangkan prevalensi untuk Lampung 1,2 per 1000 penduduk.

Deteksi dini merupakan kunci upaya penyembuhan semua jenis kanker. Pentingnya deteksi dini dilakukan untuk mengurangi prevalensi penderita dan mencegah terjadinya kondisi kanker pada stadium lanjut. Berdasarkan data rutin Subdit Kanker Direktorat Penyakit Tidak Menular, Direktorat Jenderal Pengendalian Penyakit dan Penyehatan Lingkungan, Kementerian Kesehatan RI, program deteksi dini kanker serviks sampai dengan tahun 2014 baru berjalan pada 1.986 Puskesmas dari total 9.422 Puskesmas di 304 kabupaten/kota dari 34 provinsi di Indonesia. Dengan demikian, dapat dilihat bahwa Puskesmas yang memiliki program deteksi dini masih sangat sedikit atau sekitar 21,1\%. Masalah yang menghadang dalam penanggulangan kanker serviks tersebut adalah masih rendahnya angka cakupan deteksi dini atau skrining kanker. Cakupan hasil kegiatan dari tahun 2007-2014 berkisar 904.099 orang $(2,45 \%)$ dengan hasil IVA positif sebanyak 44.654 orang $(4,94 \%)$, suspek kanker leher rahim sebanyak 1.056 orang (1,2 per 1.000 orang). Terlihat bahwa cakupan dari skrining kanker serviks masih sedikit, sehingga kegiatan deteksi dini perlu terus diperkuat di daerah yang sudah mengembangkan dan diperluas ke daerah lain yang belum mengembangkan program tersebut (Kemenkes, 2015).

Data dari Dinas Kesehatan Kabupaten Lampung Selatan tahun 2016 menyebutkan bahwa jumlah wanita usia subur usia 30-50 tahun yang telah dilakukan pemeriksaan IVA sebanyak 14.359 orang dan yang hasilnya positif sebanyak 282 kasus (1,96\%). Pada tahun 2017 mengalami peningkatan yaitu sebanyak 40.987 orang yang dilakukan pemeriksaan IVA dan yang dinyatakan positif sebanyak 603 kasus (1,47\%). Sedangkan pada tahun 2018 sebanyak 44.913 orang $(30,5 \%)$ yang telah dilakukan pemeriksaan IVA dengan hasil positif sebanyak 624 kasus (1,39\%). Untuk meningkatkan jejaring deteksi dini kanker servik ini, pada tahun 2019 Dinas Kesehatan Kabupaten Lampung Selatan menetapkan bahwa target dari jejaring deteksi dini kanker servik di Rumah Sakit dan Puskesmas adalah 50\%. (Dinas Kesehatan Lampung Selatan, 2018). Berdasarkan survey awal diketahui bahwa jumlah ibu yang melakukan deteksi dini kanker serviks melalui metode IVA di Puskesmas Kabupaten Lampung Selatan sampai dengan bulan Oktober 2019 sebanyak 54.783 orang $(36,9 \%)$ dari 148.599 orang wanita usia subur (WUS) yang berarti masih belum mencapai target yang telah ditetapkan yaitu sebesar 50\% untuk tahun 2019.

Tes Inspeksi Asam Asetat (Tes IVA) adalah suatu metode skrining kanker serviks dengan menggunakan larutan asam asetat 3-5\% pada serviks dan melihat perubahan warna yang terjadi setelah dilakukan olesan yang bertujuan untuk melihat adanya sel serviks yang mengalami displasia (Kemenkes, 2013). Hasil penelitian Mulyono dalam Mulyati (2015), di

Siti Mariam ${ }^{1}$, Atikah Adyas ${ }^{2}$, William Arisandi ${ }^{3}$

${ }^{1}$ Mahasiswa Prodi Magister Kesehatan Masyarakat UMI. Email: sitimariam651@gmail.com

${ }^{2}$ Dosen Prodi Magister Kesehatan Masyarakat UMI. Email: adyas_atikah@yahoo.com

${ }^{3}$ Dosen Prodi Magister Kesehatan Masyarakat UMI. Email: william@gmail.com 
Semarang pada 120 wanita usia subur menunjukkan hasil sensitivitas tes IVA adalah $84 \%$ dan spesifitas $89 \%$. Hal ini sesuai juga dengan penelitan Arbyn (2014) pada 58.000 wanita di India dan Afrika dengan hasil penelitian yang menunjukkan sensitivitas tes IVA adalah $83 \%$ dan spesifitas $85 \%$.

\section{Banyak faktor yang}

berhubungan dengan perilaku wanita usia subur (WUS) dalam melakukan deteksi dini kanker serviks dengan tes IVA diantaranya adalah pengetahuan, sikap, pendidikan, dukungan suami/keluarga, peran petugas kesehatan, akses informasi, akses menuju pelayanan kesehatan, keterjangkauan biaya dan dukungan teman. Hasil penelitian menunjukkan bahwa persepsi yang salah (seperti tidak perlu memeriksakan diri karena tidak adanya gejala kanker, kanker serviks hanya untuk wanita yang berperilaku seksual yang tidak aman) dapat mempengaruhi keikutsertaan deteksi dini kanker serviks. Partisipasi wanita untuk pemeriksaan Inspeksi Asam Asetat (IVA) masih minim, akibatnya mayoritas untuk mengetahui setelah stadium tinggi sehingga peluang kesembuhannya makin kecil. Menurut Lawrence Green (1993) dalam Notoatmodjo (2014), bahwa kesehatan seseorang atau masyarakat dipengaruhi oleh faktorfaktor, yakni faktor perilaku dan faktor diluar perilaku, selanjutnya perilaku itu sendiri ditentukan atau dibentuk dari 3 faktor yaitu Faktor predisposisi yang terwujud dalam pengetahuan, sikap, kepercayaan, keyakinan, nilai-nilai dan sebagainya. Penelitian ini bertujuan untuk mengetahui faktor apakah yang dominan berhubungan dengan perilaku wanita dalam melakukan deteksi dini kanker serviks di Kabupaten Lampung Selatan.

\section{METODE PENELITIAN}

Jenis penelitian adalah kuantitatif. Desain penelitian analitik dengan pendekatan crosssectional. Populasi dalam penelitian ini sebanyak 148.599 orang dengan jumlah sampel 170 responden yang ditentukan dengan menggunakan teknik Proportional Random Sampling. Data yang digunakan adalah data primer dengan menggunakan kuesioner. Analisis data menggunakan analisis univariat dengan persentase, analisis bivariat dengan Chi Square dan analisis multivariat dengan regresi logistic berganda model prediktif. Pengolahan data menggunakan aplikasi SPSS versi 20.

\section{HASIL}

ANALISIS UNIVARIAT

Tabel 1

Distribusi Frekuensi Perilaku WUS

Pemeriksaan Jumlah Persentase

IVA

(n)

(\%)

$\begin{array}{lcc}\text { Periksa IVA } & 68 & 40,0 \\ \text { Tidak Periksa } & 102 & 60,0\end{array}$

IVA

$\begin{array}{lll}\text { Total } & 170 & 100,0\end{array}$

Berdasarkan tabel diatas, sebagian besar responden tidak melakukan deteksi dini kanker serviks dengan metode IVA yaitu sebanyak 102 $(60,0 \%)$ orang.

Tabel 2

Distribusi Frekuensi Faktor Pendukung

Variabel Jumlah Persentase

(n)

\begin{tabular}{lcc}
\hline Pengetahuan & & \\
\hline$-\quad$ Baik & 40 & 23,5 \\
$-\quad$ Kurang Baik & 130 & 76,5 \\
\hline Total & 170 & 100,0 \\
\hline Sikap & & \\
\hline$-\quad$ Positif & 53 & 31,2 \\
$-\quad$ Negatif & 117 & 68,8 \\
\hline Total & 170 & 100,0 \\
\hline Pendidikan & & \\
\hline
\end{tabular}

Siti Mariam ${ }^{1}$, Atikah Adyas ${ }^{2}$, William Arisandi ${ }^{3}$

${ }^{1}$ Mahasiswa Prodi Magister Kesehatan Masyarakat UMI. Email: sitimariam651@gmail.com

${ }^{2}$ Dosen Prodi Magister Kesehatan Masyarakat UMI. Email: adyas_atikah@yahoo.com

${ }^{3}$ Dosen Prodi Magister Kesehatan Masyarakat UMI. Email: william@gmail.com 


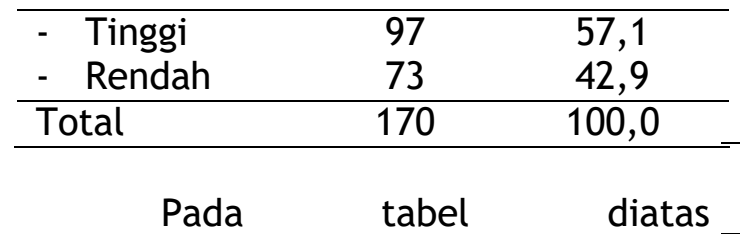

Tabel 4

Distribusi Frekuensi Faktor Pemungkin

memperlihatkan bahwa sebagian besar responden memiliki pengetahuan yang kurang baik tentang deteksi dini kanker serviks yaitu sebanyak 130 orang (76,5\%). Responden yang memiliki sikap negatif terhadap deteksi dini kanker serviks masih cukup banyak yaitu 117 orang $(68,8 \%)$, Variabel Jumlah Persentase (n) (\%) sementara responden sebagian besar Keterjangkauan Biaya mempunyai pendidikan yang tinggi yaitu sebanyak 97 orang $(57,1 \%)$.

Tabel 3 Distribusi Frekuensi Faktor Penguat Variabel Jumlah Persentase (n) (\%)

\begin{tabular}{|c|c|c|}
\hline \multicolumn{3}{|c|}{ Dukungan suami/keluarga } \\
\hline - Positif & 43 & 25,3 \\
\hline Negatif & 127 & 74,7 \\
\hline Total & 170 & 100,0 \\
\hline \multicolumn{3}{|c|}{ Peran Petugas Kesehatan } \\
\hline - Baik & 52 & 30,6 \\
\hline Kurang Baik & 118 & 69,4 \\
\hline Total & 170 & 100,0 \\
\hline \multicolumn{3}{|c|}{ Dukungan Teman } \\
\hline - Baik & 54 & 31,8 \\
\hline - Kurang & 116 & 68,2 \\
\hline Total & 170 & 100.0 \\
\hline
\end{tabular}

Tabel 3 memperlihatkan bahwa sebagian besar responden mendapatkan dukungan suami yang negatif yaitu sebanyak 127 orang $(74,7 \%)$, responden yang mendapatkan peran petugas kesehatan kurang baik yaitu sebanyak 118 orang $(69,4)$ dan sebagian besar responden mendapatkan dukungan teman yang kurang baik yaitu sebanyak 116 orang $(68,2 \%)$.

\begin{tabular}{lcc}
\hline Akses Informasi & & \\
\hline$-\quad$ Baik & 34 & 20,0 \\
$-\quad$ Kurang Baik & 136 & 80,0 \\
\hline Total & 170 & 100,0 \\
\hline
\end{tabular}

Akses ke pelayanan kesehatan

\begin{tabular}{lll}
\hline - Mudah & 69 & 40,6
\end{tabular}

$101 \quad 59,4$

$170 \quad 100,0$

$\begin{array}{lcc}\text { - Mampu } & 65 & 38,2 \\ \text { - Tidak } & 105 & 61,8\end{array}$
mampu \begin{tabular}{lll}
\hline Total & 170 & 100,0 \\
\hline
\end{tabular}

\section{Dari tabel 4 diatas diketahui} bahwa sebagian besar responden yang mempunyai akses informasi yang kurang baik terkait deteksi dini kanker serviks ini sebanyak 136 orang (80\%). Mempunyai akses ke pelayanan kesehatan yang sulit yaitu sebanyak 101 orang $(59,4 \%)$ dan banyak responden yang tergolong tidak mampu dalam keterjangkauan biaya pemeriksaan deteksi dini kanker serviks yaitu sebanyak 105 orang $(61,8 \%)$.

\section{ANALISIS BIVARIAT}

Analisis bivariat yang dihasilkan seperti yang terlihat pada tabel 5 dibawah, menunjukkan bahwa seluruh variabel yaitu pengetahuan, sikap, pendidikan, dukungan suami, peran petugas kesehatan, dukungan teman, akses informasi, akses ke pelayanan kesehatan dan keterjangkauan biaya mempunyai hubungan yang signifikan dengan perilaku wanita dalam melakukan deteksi dini kanker serviks dilihat dari semua variabel mempunyai nilai $p$ value $<0,05$.

Siti Mariam ${ }^{1}$, Atikah Adyas ${ }^{2}$, William Arisandi ${ }^{3}$

${ }^{1}$ Mahasiswa Prodi Magister Kesehatan Masyarakat UMI. Email: sitimariam651@gmail.com

${ }^{2}$ Dosen Prodi Magister Kesehatan Masyarakat UMI. Email: adyas_atikah@yahoo.com

${ }^{3}$ Dosen Prodi Magister Kesehatan Masyarakat UMI. Email: william@gmail.com 
Tabel. 5 Hasil Analisis Bivariat

Determinan Perilaku Wanita Melakukan Deteksi Dini Kanker Serviks

\begin{tabular}{|c|c|c|c|c|c|c|c|c|}
\hline \multirow{3}{*}{ Variabel Independen } & \multicolumn{4}{|c|}{ Perilaku WUS periksa IVA } & \multirow{2}{*}{\multicolumn{2}{|c|}{ Total }} & \multirow{3}{*}{$\begin{array}{c}p \\
\text { value }\end{array}$} & \multirow{3}{*}{$\begin{array}{c}\mathrm{OR} \mathrm{Cl} \\
95 \%\end{array}$} \\
\hline & \multicolumn{2}{|c|}{$\mathrm{Ya}$} & \multicolumn{2}{|c|}{ Tidak } & & & & \\
\hline & $\Sigma$ & $\%$ & $\Sigma$ & $\%$ & $\Sigma$ & $\%$ & & \\
\hline \multicolumn{9}{|l|}{ Pengetahuan } \\
\hline - $\quad$ Baik & 23 & 57,5 & 17 & 42,5 & 40 & 100 & \multirow{3}{*}{0,016} & \multirow{3}{*}{$\begin{array}{l}2,556 \\
1,239- \\
5,269\end{array}$} \\
\hline Kurang Baik & 45 & 34,6 & 85 & 65,4 & 130 & 100 & & \\
\hline Jumlah & 68 & 40,0 & 102 & 60,0 & 170 & 100 & & \\
\hline \multicolumn{9}{|l|}{ Sikap } \\
\hline - $\quad$ Positif & 29 & 54,7 & 24 & 45,3 & 53 & 100 & \multirow{3}{*}{0,014} & \multirow{3}{*}{$\begin{array}{c}2,417 \\
1,245- \\
4,692\end{array}$} \\
\hline - Negatif & 39 & 33,3 & 78 & 66,7 & 117 & 100 & & \\
\hline Jumlah & 68 & 40,0 & 102 & 60,0 & 170 & 100 & & \\
\hline \multicolumn{9}{|l|}{ Pendidikan } \\
\hline $\begin{array}{ll}- & \text { Tinggi }\end{array}$ & 47 & 48,5 & 50 & 51,5 & 97 & 100 & \multirow{3}{*}{0,015} & \multirow{3}{*}{$\begin{array}{c}2,328 \\
1,222- \\
4,434\end{array}$} \\
\hline Rendah & 21 & 28,8 & 52 & 71,2 & 73 & 100 & & \\
\hline Jumlah & 68 & 40,0 & 102 & 60,0 & 170 & 100 & & \\
\hline \multicolumn{9}{|l|}{ Dukungan Suami } \\
\hline - $\quad$ Positif & 32 & 74,4 & 11 & 25,6 & 43 & 100 & \multirow{3}{*}{0,001} & \multirow{3}{*}{$\begin{array}{l}7,354 \\
3,350- \\
16,142\end{array}$} \\
\hline Negatif & 36 & 28,3 & 91 & 71,7 & 127 & 100 & & \\
\hline Jumlah & 68 & 40,0 & 102 & 60,0 & 170 & 100 & & \\
\hline \multicolumn{9}{|c|}{ Peran Petugas Kesehatan } \\
\hline - $\quad$ Baik & 43 & 82,7 & 9 & 17,3 & 52 & 100 & \multirow{3}{*}{0,001} & \multirow{3}{*}{$\begin{array}{l}17,773 \\
7,648- \\
41,305\end{array}$} \\
\hline Kurang Baik & 25 & 21,2 & 93 & 78,8 & 118 & 100 & & \\
\hline Jumlah & 68 & 40,0 & 102 & 60,0 & 170 & 100 & & \\
\hline \multicolumn{9}{|l|}{ Dukungan Teman } \\
\hline - $\quad$ Baik & 31 & 57,4 & 23 & 42,6 & 54 & 100 & \multirow{3}{*}{0,003} & \multirow{3}{*}{$\begin{array}{l}2,878 \\
1,479- \\
5,601\end{array}$} \\
\hline Kurang Baik & 37 & 31,9 & 79 & 68,1 & 116 & 100 & & \\
\hline Jumlah & 68 & 40,0 & 102 & 60,0 & 170 & 100 & & \\
\hline Akses Informasi & & & & & & & & \\
\hline - $\quad$ Baik & 26 & 76,5 & 8 & 23,5 & 34 & 100 & & 7,274 \\
\hline Kurang Baik & 42 & 30,9 & 94 & 69,1 & 136 & 100 & 0,001 & 3,042 \\
\hline Jumlah & 68 & 40,0 & 102 & 60,0 & 170 & 100 & & 17,395 \\
\hline Akses ke Pelayanan K & seha & & & & & & & \\
\hline - $\quad$ Mudah & 50 & 72,5 & 19 & 27,5 & 69 & 100 & & 12,135 \\
\hline - $\quad$ Sulit & 18 & 17,8 & 83 & 82,2 & 101 & 100 & 0,000 & 5,825 \\
\hline Jumlah & 68 & 40,0 & 102 & 60,0 & 170 & 100 & & 25,280 \\
\hline Keterjangkauan Biaya & & & & & & & & \\
\hline - Mampu & 33 & 50,8 & 32 & 49,2 & 65 & 100 & & 2,063 \\
\hline Tidak Mampu & 35 & 33,3 & 70 & 66,7 & 105 & 100 & 0,036 & 1,095 \\
\hline Jumlah & 68 & 40,0 & 102 & 60,0 & 170 & 100 & & 3,885 \\
\hline
\end{tabular}

Siti Mariam ${ }^{1}$, Atikah Adyas $^{2}$, William Arisandi ${ }^{3}$

${ }^{1}$ Mahasiswa Prodi Magister Kesehatan Masyarakat UMI. Email: sitimariam651@gmail.com

${ }^{2}$ Dosen Prodi Magister Kesehatan Masyarakat UMI. Email: adyas_atikah@yahoo.com

${ }^{3}$ Dosen Prodi Magister Kesehatan Masyarakat UMI. Email: william@gmail.com 
ANALISIS MULTIVARIAT

Tabel 6

Hasil Akhir Uji Regresi Logistik Ganda

\begin{tabular}{|c|c|c|c|c|}
\hline No & Variabel & B & Sig. & $\operatorname{Exp}(B)$ \\
\hline 1. & Pengetahuan & 1,353 & , 019 & 3,871 \\
\hline 2. & Dukungan suami & 1,609 & ,006 & 4,997 \\
\hline 3. & Peran petugas kesehatan & 2,719 & ,000 & 15,164 \\
\hline 4. & Akses informasi & 1,112 & ,096 & 3,041 \\
\hline 5. & Akses ke yankes & 2,739 & ,000 & 15,466 \\
\hline & Constant & $-3,475$ & ,000 & ,031 \\
\hline
\end{tabular}

Hasil akhir analisis multivariat menggunakan regresi logistk ini didapatkan bahwa terdapat 5 variabel yang dinyatakan sebagai faktor-faktor yang berhubungan dengan perilaku wanita dalam melakukan deteksi dini kanker serviks. Variabel yang paling dominan adalah akses ke pelayanan kesehatan dengan nilai OR sebesar 15,46 yang berarti bahwa wanita usia subur yang memiliki akses ke pelayanan kesehatan yang mudah mempunyai peluang untuk melakukan deteksi dini kanker serviks melalui metode IVA sebesar 15,46 kali lebih besar dibandingkan dengan wanita usia subur dengan akses ke pelayanan kesehatan yang sulit setelah dikontrol oleh variabel pengetahuan, dukungan suami, peran petugas kesehatan dan akses informasi.

\section{PEMBAHASAN}

Hubungan Pengetahuan Dengan Perilaku Wanita Dalam Melakukan Menurut peneliti, dalam hal deteksi dini kanker serviks ini, wanita usia subur di tuntut untuk memenuhi minimal 3 tingkatan dari ranah kognitif (intelektual) menurut Bloom yaitu bukan hanya sekedar tahu (C1) tentang informasi pentingnya deteksi dini kanker serviks bagi kesehatan reproduksi dan bagi kelangsungan hidupnya, tetapi wanita usia subur di harapkan mampu memahami secara mendalam dengan cara dapat menjelaskan kembali dan memperluas arti dengan bahasa nya sendiri tentang pentingnya deteksi dini tersebut (C2), kemudian setelah didapatkan pemahaman, wanita usia subur harus dapat menerapkan atau melaksanakan informasi yang telah di ketahui dan di pahami nya tersebut secara nyata yaitu dengan bersedia melakukan deteksi dini kanker serviks dengan pemeriksaan IVA dengan kesadaran penuh karena wanita usia subur tersebut telah mengetahui dan mempunyai pemahaman yang mendalam (C3).

Hubungan Sikap Dengan Perilaku Wanita Dalam Melakukan Deteksi Dini Kanker Serviks

Peneliti berasumsi bahwa sikap positif dari individu tidak serta merta berujung pada perilaku kesehatan yang baik pula, berbagai faktor perancu akan menghampiri dan dapat merubah sikap positif tadi menjadi perilaku yang tidak positif. Faktor perancu tersebut terkait dengan faktor status sosial ekonomi dan takut jika di ketahui penyakitnya. Sehingga walaupun responden bersikap positif namun tetap enggan melakukan deteksi

Siti Mariam ${ }^{1}$, Atikah Adyas ${ }^{2}$, William Arisandi ${ }^{3}$

${ }^{1}$ Mahasiswa Prodi Magister Kesehatan Masyarakat UMI. Email: sitimariam651@gmail.com

${ }^{2}$ Dosen Prodi Magister Kesehatan Masyarakat UMI. Email: adyas_atikah@yahoo.com

${ }^{3}$ Dosen Prodi Magister Kesehatan Masyarakat UMI. Email: william@gmail.com 
dini kanker serviks. Namun, sebagian besar individu yang berangkat dari pengetahuan, persepsi dan sikap yang positif terhadap suatu topik masalah kesehatan. Maka, kemungkinan untuk terjadi eksekusi perilaku kesehatan yang positifpun akan lebih besar.

Hubungan Pendidikan Dengan Perilaku Wanita Dalam Melakukan Deteksi Dini Kanker Serviks

Menurut pendapat peneliti pendidikan akan mempengaruhi pengetahuan seseorang, dan pengetahuan tidak hanya bisa di dapat dari pendidikan secara formal melainkan ada yang didapat secara informal salah satunya pendidikan yang didapat responden berasal dari kegiatan yang sering dilakukan secara rutin seperti pada kegiatan posyandu, posbindu, pengajian, pertemuan PKK yang secara tidak langsung dapat meningkatkan pengetahuan wanita usia subur. Tingkat pendidikan merupakan salah satu faktor yang sangat menentukan pengetahuan dan persepsi seseorang terhadap pentingnya suatu hal termasuk pentingnya deteksi dini kanker serviks, disebabkan seseorang yang berpendidikan tinggi akan lebih luas pandangannya dan lebih mudah menerima ide dan tata cara kehidupan baru. Sehingga dapat disimpulkan bahwa orang yang berpendidikan tinggi akan melakukan deteksi dini kanker serviks.

Hubungan Dukungan Suami Dengan Perilaku Wanita Dalam Melakukan Deteksi Dini Kanker Serviks Responden yang mendapatkan dukungan dari keluarga yang baik akan lebih besar kemungkinan untuk melakukan pemeriksaan IVA. Hal ini disebabkan adanya pengaruh yang kuat dari orang terdekat atau suami akan cenderung membuat responden lebih termotivasi meningkatkan taraf kesehatannya. Selain itu, peran suami sebagai pengambil keputusan akan sangat mempengaruhi perilaku WUS tersebut dalam melakukan pemeriksaan IVA.

Berdasarkan hasil penelitian dimana pada responden yang didukung suami tetapi masih tetap tidak melakukan deteksi dini kanker serviks, peneliti berasumsi hal ini bisa dikarenakan karena walaupun mendapat dukungan suami, namun ketika responden tidak mau dan merasa tidak siap melakukan deteksi dini, pada akhirnya akan mempengaruhi keputusan responden dalam melakukan deteksi dini kanker serviks.

\section{Hubungan Peran Petugas Kesehatan Dengan Perilaku Wanita Dalam Melakukan Deteksi Dini Kanker Serviks \\ Menurut peneliti peran} petugas kesehatan dianggap penting dan berpengaruh dalam perilaku kesehatan di masyarakat. Namun tidak semua responden yang mendapat dukungan petugas melakukan pemeriksaan deteksi dini hal ini dimungkinkan karena responden merasa awam dan malu akan perlakuan tindakan yang akan diterima serta takut akan hasil pemeriksaan yang didapat. Sehingga walau sudah mendapat dukungan petugas kesehatan tentang pemeriksaan deteksi dini tetap tidak mau melakukan pemeriksaan deteksi dini kanker leher rahim. Pada responden yang tidak mendapat dukungan petugas namun memeriksakan diri hal ini di mungkinkan karena responden disuruh orang yang berpengaruh atau ikut-ikutan teman tanpa tahu tujuan dan manfaat dari 
pemeriksaan deteksi dini kanker leher rahim.

Hubungan Dukungan
Dengan Perilaku Wanita
$\begin{aligned} & \text { Melakukan } \\ & \text { Selam }\end{aligned}$
Serviks
Sebaiknya penyampaian informasi yang efektif dari petugas kesehatan tidak bersifat searah saja, tetapi dua arah. Hal ini berarti bahwa petugas kesehatan tidak hanya sekedar memberikan informasi saja, namun juga memotivasi masyarakat untuk aktif berpartisipasi melakukan diskusi tentang informasi yang diterimanya. Sehingga pengetahuan yang terbentuk dapat lebih mantap dan mendalam. Penyampaian informasi yang baik antara petugas kesehatan dengan masyarakat dan antara masyarakat itu sendiri berkontribusi positif terhadap perilaku pemeriksaan deteksi dini kanker serviks.

Hubungan Akses ke Pelayanan Kesehatan Dengan Perilaku Wanita Dalam Melakukan Deteksi Dini Kanker Serviks

Hasil penelitian ini sesuai dengan teori Lawrence Green dalam Priyoto (2014), bahwa jarak dan ketersediaan transportasi sebagai faktor pemungkin suatu motivasi terlaksana. Kemudahan akses dan pemanfaatan pelayanan kesehatan berhubungan dengan beberapa faktor penentu yang salah satunya adalah jarak tempat tinggal ke sarana pelayanan kesehatan. Hasil penelitian ini sesuai dengan penelitian dari Rohmawati (2011), yang menyatakan bahwa ada hubungan dengan antara akses menuju pelayanan kesehatan dengan perilaku ibu dalam pemeriksaan kanker serviks dengan IVA. Penelitian tersebut menjelaskan kemudahan akses dan pemanfaatan pelayanan kesehatan berhubungan dengan beberapa faktor penentu yang salah satunya adalah jarak tempat tinggal ke sarana pelayanan kesehatan.

Hubungan Keterjangkauan Biaya Dengan Perilaku Wanita Dalam Melakukan Deteksi Dini Kanker Serviks

Keterjangkauan biaya merupakan faktor pemungkin seseorang melakukan pemeriksaan deteksi dini kanker leher rahim. Keterjangkauan biaya ini dimungkinkan karena tersedianya perlindungan kesehatan yang diberikan pemerintah pusat (Katu Indonesia Sehat) dan pemerintah kota (BPJS) serta kebijakan pemerintah yang mengratiskan pemeriksaan deteksi dini kanker leher rahim kususnya IVA dipuskesmas.

\section{Variabel Yang Dominan}

Dari hasil penelitian ini, peneliti dapat menyimpulkan bahwa variabel akses ke pelayanan kesehatan adalah merupakan faktor yang paling dominan/penting yang berarti bahwa wanita usia subur yang memiliki akses ke pelayanan kesehatan yang mudah mempunyai peluang yang lebih besar untuk melakukan deteksi dini kanker serviks melalui metode IVA dibandingkan dengan wanita usia subur dengan akses ke pelayanan kesehatan yang sulit setelah dikontrol oleh variabel pengetahuan, dukungan suami, peran petugas kesehatan dan akses informasi dan faktor counfounding yaitu keterjangkauan biaya.

\section{SIMPULAN}

Proporsi wanita usia subur yang melakukan deteksi dini kanker serviks metode Inspeksi Visual Asam Asetat (IVA) di Puskesmas Kabupaten Lampung Selatan Tahun

Siti Mariam ${ }^{1}$, Atikah Adyas ${ }^{2}$, William Arisandi ${ }^{3}$

${ }^{1}$ Mahasiswa Prodi Magister Kesehatan Masyarakat UMI. Email: sitimariam651@gmail.com

${ }^{2}$ Dosen Prodi Magister Kesehatan Masyarakat UMI. Email: adyas_atikah@yahoo.com

${ }^{3}$ Dosen Prodi Magister Kesehatan Masyarakat UMI. Email: william@gmail.com 
2020 sebanyak 68 orang (40\%). Ada hubungan yang signifikan antara faktor pendukung dengan perilaku wanita usia subur dalam deteksi dini kanker serviks. Ada hubungan yang signifikan antara faktor penguat dengan perilaku wanita usia subur dalam deteksi dini kanker serviks. Ada hubungan yang signifikan antara faktor pemungkin dengan perilaku wanita usia subur dalam deteksi dini kanker serviks.

Variabel yang dominan berhubungan dengan perilaku wanita usia subur dalam deteksi dini kanker serviks metode Inspeksi Visual Asam Asetat (IVA) di Puskesmas Kabupaten Lampung Selatan Tahun 2020 adalah variabel akses ke pelayanan kesehatan yaitu sebesar 15,46 yang berarti bahwa wanita usia subur yang memiliki akses ke pelayanan kesehatan yang mudah mempunyai peluang untuk melakukan deteksi dini kanker serviks melalui metode IVA sebesar 15,46 kali lebih besar dibandingkan dengan wanita usia subur dengan akses ke pelayanan kesehatan yang sulit setelah dikontrol oleh variabel pengetahuan, dukungan suami, peran petugas kesehatan dan akses informasi.

\section{SARAN}

Bagi Puskesmas di Kabupaten Lampung Selatan terus meningkatkan upaya promosi melalui Komunikasi Informasi dan Edukasi (KIE) yang efektif tentang deteksi dini kanker serviks dan juga pemilihan metode yang tepat agar para wanita usia subur tersebut dapat mencapai ranah kognitif di tingkat analisis (C4) sehingga program deteksi dini kanker serviks ini dapat berhasil dan prevalensi kanker di Indonesia dapat menurun secara signifikan. Bagi Pemerintah Daerah diharapkan selalu memberikan dukungan baik dalam hal promosi kepada masyarakat ataupun suport pembiayaan untuk mendukung kegiatan pemeriksaan deteksi dini kanker serviks, pemberlakuan reward dan sanksi bagi petugas kesehatan yang tidak komitmen dalam pelayanan deteksi dini kanker serviks. Dan yang utama adalah untuk pemerintahan di level pusat dimohonkan untuk mengembalikan klaim dana kapitasi (BPJS) untuk pemeriksaan deteksi dini dengan pemeriksaan IVA ini. Hasil penelitian ini dapat bermanfaat dan dapat digunakan sebagai bahan pembanding, dapat mengembangkan variabel penelitian, dapat meminimalkan kelemahan/keterbatasan dalam penelitian ini.

\section{DAFTAR PUSTAKA}

American Cancer Society (2018), Cervical cancer prevention and early detection, Atlanta, GA : American Cancer Society 2018.

Anggraeni, Nobelia. (2015). Hubungan Tingkat Pengetahuan Tentang Kanker Serviks Dengan Perilaku WUS Melakukan Pemeriksaan IVA Di Puskesmas Banguntapan I Bantul.

Asni, Nur Arti. (2016). Determinan Faktor Deteksi Dini Kanker Serviks Dengan Metode IVA Pada Wanita PUS di Desa Payageli Kecamatan Sunggal Kabupaten Deli Serdang.

Astuti, Rini., Dkk. (2018) Hubungan Tingkat Pengetahuan Dan Motivasi Ibu Dengan Perilaku Pemeriksaan IVA Di UPTD Puskesmas Tomia Sulawesi Tenggara Tahun 2018

Aulia Citra, Shufia Dkk., (2019). Hubungan Dukungan Petugas Kesehatan Dengan Perilaku WUS (Wanita Usia Subur) Dalam Pemeriksaan IVA Di Puskesmas Banguntapan I Bantul

Siti Mariam ${ }^{1}$, Atikah Adyas ${ }^{2}$, William Arisandi ${ }^{3}$

${ }^{1}$ Mahasiswa Prodi Magister Kesehatan Masyarakat UMI. Email: sitimariam651@gmail.com

${ }^{2}$ Dosen Prodi Magister Kesehatan Masyarakat UMI. Email: adyas_atikah@yahoo.com

${ }^{3}$ Dosen Prodi Magister Kesehatan Masyarakat UMI. Email: william@gmail.com 
Yogyakarta. Universitas 'Aisyiyah Yogyakarta tahun 2019.

Azwar, Saifudin. (2016). Sikap Manusia Teori dan Pengukurannya. Jakarta : Rineka Cipta.

Badan Penelitian dan Pengembangan Kesehatan Kemenkes RI., (2013). Riset Kesehatan Dasar, 2013 (diakses pada tanggal 22 November 2019, jam 17:44 WIB).

Badan Penelitian dan Pengembangan Kesehatan Kemenkes RI., (2018). Riset Kesehatan Dasar, 2018 (diakses pada tanggal 22 November 2019, jam 15:40 WIB).

Basu, Partha dkk., (2014). DOI:http://dx.doi.org/10.7314/A PJCP.2014.15.16.6691, Knowledge of Women in Maldives Related to the Risk Factors, Prevention and Early Detection of Cervical Cancer (diakses pada tanggal 20 November 2019, jam 16:10 WIB).

Budiman, (2013). Kapita Selekta Kuesioner Pengetahuan, Jakarta : Salemba Medika.

Chandra, Budiman, (2013). Metodologi Penelitian Kesehatan, Jakarta : EGC.

Dahlan, Sopiyudin. (2012). Langkahlangkah Membuat Proposal Penelitian Bidang Kedokteran dan Kesehatan. Jakarta : CV Sagung Seto. 2012

Dahlan, Sopiyudin. (2014). Statistik Untuk Kedokteran dan Kesehatan. Jakarta Epidemiologi Indonesia. 2014

Dahlan, Sopiyudin. (2016). Pintu Gerbang Mamahami Epidemiologi, Biostatistik dan Metode Penelitian. Jakarta : Epidemiologi Indonesia. 2016

Dahlan, Sopiyudin. (2016). Besar Sampel Dalam Penelitian Kedokteran dan Kesehatan.
Jakarta : Epidemiologi Indonesia. 2016

Dahlan, Sopiyudin. (2016). Analisis Multivariat Regresi Logistik. Jakarta : Epidemiologi Indonesia. 2016

Dinas Kesehatan Provinsi Lampung, 2017. Profil Kesehatan Dinas Kesehatan Provinsi lampung Tahun (2016). (diakses pada tanggal 18 November 2019, pukul 20.00 WIB).

Dinas Kesehatan Lampung Selatan, (2018). Profil Kesehatan Dinas Kesehatan Lampung Selatan Tahun 2017 (diakses pada tanggal 20 November 2019, pukul 10.00 WIB).

Dinas Kesehatan Lampung Selatan, (2019). Data Cakupan Pemeriksaan IVA sampai dengan Oktober 2019 di Puskesmas Kabupaten Lampung Selatan. Kasie PPTM Dinas Kesehatan Lampung Selatan.

Dewi, L. (2014). Faktor-Faktor yang Berhubungan dengan Perilaku WUS Dalam Deteksi Dini Kanker Leher Rahim Metode IVA Di Wilayah Kerja Puskesmas Tanjung Hulu. Pontianak: FK UTP. Diakses pada tanggal 20 November 2019.

D. Subhankar, B.Sudhindra, (2011). Is visual inspection with acetic acid better than cervical cytology to screen women, 40 years of age for carcinoma cervix? (diakses pada tanggal 22 November 2019, jam 16:40 WIB).

Dwika G., (2014). Faktor-Faktor yang Berhubungan Dengan Perilaku Pencegahan Kanker Serviks Pada Wanita Usia Subur. JOM PSIK. Vol. 1. No 2. Oktober 2014. hlm. 1-8.

Emilia, Ova, dkk., (2014). Bebas Ancaman Kanker Serviks, Cetakan 1, Yogyakarta : Media Pressindo. 
Febriani, Christin Angelina. (2016). Faktor-Faktor Yang Berhubungan Dengan Deteksi Dini Kanker Leher Rahim Di Kecamatan Gisting Kabupaten Tanggamus Lampung. Fakultas Kesehatan Masyarakat, Universitas Malahayati Bandar Lampung tahun 2016.

Fitriani, S. (2012). Promosi Kesehatan. Ed 1. Yogyakarta: Graha Ilmu.

Green, W Lawrence. (2005). Health education planning $A$ diagnostic approach the John Hapkins University; Mayfieltd publication company

Hastono, Sutanto Priyo. (2016). Analisa Data Kesehatan. FKM UI Jakarta

Hidayat, Alimul Aziz. (2012). Kebutuhan Dasar Manusia Jakarta : Salemba Medika

Kamaliah, (2011). Pengaruh pengetahuan, sikap, kepercayaan dan tradisi wanita usia subur (WUS) terhadap pemeriksaan pap smear dalam upaya deteksi dini kanker serviks di RSUD Dr.Pirngadi Medan, http://repository.usu.id, (diakses pada tanggal 17 November 2019, jam 19:13 wib).

K. Aygul, (2014). International Journalof Caring Sciences, Perceptions of Barriers and Facilitators of Cervical Cancer Early Detection Behaviors among Elderly Women, (diakses pada tanggal 22 November 2019, jam 11:02 WIB).

Kementerian Kesehatan RI, (2013). Insiden kanker serviks di Indonesia. Jakarta. Direktorat Jenderal Pengendalian Penyakit dan Penyehatan Lingkungan

Kementerian Kesehatan RI, (2014). Deteksi dini kanker leher rahim. Jakarta. Subdit Kanker Direktorat Jenderal Pengendalian Penyakit dan Penyehatan Lingkungan
Kementerian Kesehatan RI, (2015). Panduan Program Nasional Gerakan Pencegahan dan Deteksi Dini Kanker Leher Rahim dan Kanker Payudara April 2015, www.depkes.go.id. (diakses tanggal 18 November 2019, jam 20:20 WIB)

Kemenkes RI., (2015). Peraturan Menteri Kesehatan Republik Indonesia Nomor 34 Tahun 2015, Penanggulangan Kanker Payudara dan Kanker Leher Rahim (diakses pada tanggal 18 November 2019, jam 19:14 WIB).

Kholid, Ahmad, (2012). Promosi Kesehatan dengan Pendekatan Perilaku, Media dan Aplikasinya, Cetakan 1, Jakarta : Rajawali Pers.

Khosidah, Amik dkk. (2015). FaktorFaktor yang Mempengaruhi Ibu Rumah Tangga Dalam Melakukan Tes IVA Sebagai Upaya Deteksi Dini Kanker Serviks. Jurnal Ilmiah Kebidanan. Vol 6 . No 2. Desember 2015. HIm 94-105.

Kurniawati, Indah. (2015). Pengaruh pengetahuan, motivasi dan dukungan suami terhadap perilaku pemeriksaan IVA pada kelompok wanita usia subur di Puskesmas Kedungrejo. Master Thesis, Universitas Sebelas Maret.

Lailawati, Arini. (2015). Hubungan Dukungan Petugas Kesehatan dengan Kunjungan PUS Dalam Melakukan Skrining Kanker Serviks Menggunakan Metode IVA di Desa Bojonglor Kecamatan Bojong Kabupaten Pekalongan. Skripsi, STIKES Muhammadiyah Pekajangan Pekalongan.

Masturoh, Eminia. (2016). Faktor Faktor yang Mempengaruhi Wanita Usia Subur (WUS) dalam Melakukan Deteksi Dini Kanker Serviks dengan Inspeksi Visual Asam Asetat (IVA) di Wilayah

Siti Mariam ${ }^{1}$, Atikah Adyas ${ }^{2}$, William Arisandi ${ }^{3}$

${ }^{1}$ Mahasiswa Prodi Magister Kesehatan Masyarakat UMI. Email: sitimariam651@gmail.com

${ }^{2}$ Dosen Prodi Magister Kesehatan Masyarakat UMI. Email: adyas_atikah@yahoo.com

${ }^{3}$ Dosen Prodi Magister Kesehatan Masyarakat UMI. Email: william@gmail.com 
Kerja Puskesmas Bangetayu Kota Semarang

Megan J.dkk., (2010). A Comparison of two visual inspection methods for cervical cancer screening among HIV-infected women in Kenya, http : //eresources. perpusnas.go.id, (diakses pada tanggal 21 November 2019, jam 11:05).

Mingshan Lu, (2012). A systematic review of interventions to increase breast and cervical cancer screening uptake among Asian women (diakses pada tanggal 21 November 2019, jam 12:01 WIB).

M. Deasy dkk., (2013). http : //jurnal.untan.ac.id, Hubungan antara tingkat pengetahuan tentang kanker serviks dan keikutsertaan melakukan pemeriksaan inspeksi visual asetat di puskesmas Alianyang Pontianak (diakses pada tanggal 20 November 2019, jam 09:15 WIB).

Mubarak, (2012). Promosi Kesehatan Untuk Kebidanan. Jakarta : Salemba Medika

Mulyati, S., Suwarsa, O., \& Arya, L.F.D. (2015). Pengaruh media film terhadap sikap ibu pada deteksi dini kanker serviks. Jurnal Kesehatan Masyarakat, 11(1), 16-24.

Nainggolan. (2016). Pengaruh Akses ke fasilitas kesehatan (Analisis Riskesdas, 2013). Jurnal Kementerian Kesehatan RI.

Ningrum, R.D., \& Fajarsari, D. (2012). Faktor-faktor Yang Mempengaruhi Motivasi Ibu mengikuti deteksi dini kanker serviks melalui metode IVA di Kabupaten Banyumas 2012. Bidan Prada : Jurnal publikasi kebidanan AKBID YLPP Purwokerto, 4(01).

$\mathrm{Ni}$ Wayan S., (2012). Pengetahuan dan motivasi wanita usia subur tentang tes inspeksi visual asam asetat di Provinsi Bali Indonesia (diakses pada tanggal 18 November 2019, jam 12:45 wib).

Notoatmodjo, Soekidjo, (2012). Promosi Kesehatan dan Perilaku Kesehatan, Edisi Revisi, Jakarta : Rineka Cipta.

Notoatmodjo, Soekidjo, (2014). Kesehatan Masyarakat IImu dan Seni. Jakarta: Rineka Cipta

Nuranna, L. (2008). Skrining kanker servik dengan metode IVA, Jurnal Dunia Kedokteran. From http:// www.kalbe.co.id di akses tgl 27 November 2018 Ramli. 2005. Deteksi Dini Kanker. Jakarta: FKUI

Padila. (2012). Buku ajar keperawatan keluarga. Jogjakarta : Nuha Medika

Priyoto. (2014). Teori Sikap dan Perilaku dalam Kesehatan. Yogyakarta: Nuha Medika.

Rahayu, Dedeh sri.(2015). Asuhan Ibu dengan Kanker Serviks. Jakarta: Salemba Medika.

S. Eva, M.S. Anna, (2012). http : //e-

journal.litbang.depkes.go.id, Pengetahuan tentang faktor risiko, perilaku dan detiksi dini kanker serviks dengan inspeksi visual asam asetat (IVA) pada wanita di kecamatan Bogor tengah, Kota Bogor, (diakses pada tanggal 22 November 2019, jam 10:15 wib).

Setiati, Eni, (2012). Kenali Penanganan Tumor dan Kanker Pada Wanita, Cetakan 1, Jakarta : Pustaka Rama.

Sihombing, Moina., Cicilia Windiyaningsih., (2015). Faktor Penentu Pemeriksaan IVA Pada Wanita Usia Subur Di Puskesmas Pademangan, Suku Dinas Kesehatan Jakarta Utara 2015. Jurnal Bidang Ilmu Kesehatan Vol. 7 No. 1, Juni 2016 
Siswanto Agus Wilopo. (2010). Epidemiologi dan Pencegahan Kanker Leher Rahim. Yogyakarta: Universitas Gajah Mada

Siti Lestari, Indah. (2016). FaktorFaktor Yang Mempengaruhi Kesediaan WUS Dalam Melakukan Deteksi Dini Kanker Serviks Di Puskesmas Manahan Surakarta tahun 2016.

Soerjomataram, Ferlay J, I, Ervik M, Dikshit R, Eser S, Mathers C, Rebelo M, Parkin DM, Forman D, Bray, F. GLOBOCAN 2012v1.0, Statistic of Cervical Cancer, Cancer Incidence and Mortality Worldwide : IARC Cancer Base No.11(Internet) Lyon France : International Agency for Research on Cancer, 2013.

Sofiana, Nurcahyati. (2014). Faktor yang Berhubungan dengan Pencegahan Kanker Serviks Pada Wanita Usia Subur. Artikel Kesehatan. Vol. 1 No. 2.

Sugiyono. (2016). Metode Penelitian Kuantitatif Kualitatif Dan R\&D. Bandung: Alfabeta.

Sulistiowati, Eva, Anna Maria Sirait. (2014). Pengetahuan Tentang Faktor Resiko Perilaku dan Deteksi Dini Kanker Serviks dengan Inspeksi Asam Asetat (IVA) pada Wanita di Kecamaatan Bogor Tengah kota Bogor. Pusat Teknologi Intervensi Kesehatan Masyarakat Badan Penelitian dan Pengembangan Kesehatan Kementrian Kesehatan RI.
Buletin Peneliti Kesehatan Vol 42, No 3, September 2014: 193202.

Sulistyaningsih, (2012). Metodologi Penelitian Kebidanan Kuantitatif-Kualitatif, Cetakan ke-2, Yogyakarta : Graha Ilmu.

Tao L, Kendall K., (2013), Sinopsis Organ Sistem Reproduksi. Tangerang, Karisma Publishing Group.

T. Frida Lina, (2012). Pengaruh dukungan keluarga dan sumber informasi terhadap perilaku wanita usia subur dalam deteksi dini kanker serviks di Kecamatan Medan http: / / repository.usu.id selayang,

WHO.,(2012). Prevention of cervical cancer through screening using visual inspection with acetic acid (VIA) and treatment with cryotherapy (diakses pada tanggal 22 November 2019, jam 10:00 WIB).

Yao Jia, (2013). Knowledge about Cervical Cancer and Barriers of Screening Program among Women in Wufeng County, a High-Incidence Region of Cervical Cancer in China (diakses pada tanggal 18 November 2019, jam 10:00 WIB).

Yuliawati. (2012)a. Faktor-faktor yang Mempengaruhi WUS Dalam Deteksi Dini Kanker Serviks Di Wilayah Puskesmas Prambun. Diakses 18 November 2019. 